\title{
Long-term effects of aliskiren on blood pressure and the renin-angiotensin-aldosterone system in hypertensive hemodialysis patients
}

This article was published in the following Dove Press journal: International Journal of Nephrology and Renovascular Disease 20 March 2012

Number of times this article has been viewed

\section{Yoshiyuki Morishita' Minami Watanabe' \\ Shiho Hanawa' \\ Osamu limura ${ }^{2}$ \\ Sadao Tsunematsu ${ }^{3}$ \\ Kenichi Ishibashi ${ }^{4}$ \\ Eiji Kusano'}

'Division of Nephrology, Department of Medicine, Jichi Medical University, Tochigi, Japan; ${ }^{2}$ Kumakura Clinic, Tochigi, Japan; ${ }^{3}$ Yuki Clinic, Ibaragi, Japan; ${ }^{4}$ Department of Medical Physiology, Meiji Pharmaceutical University, Tokyo, Japan
Correspondence: Y Morishita

Division of Nephrology,

Department of Medicine, Jichi Medical University, 33II-I, Yakushiji, Shimotsuke,

Tochigi 329-0498, Japan

$\mathrm{Tel}+8 \mathrm{I} 285587346$

Fax +8I 285444869

Email ymori@jichi.ac.jp
Objective: The long-term effects of aliskiren in hypertensive hemodialysis patients remain to be elucidated.

Design: In this post hoc analysis, we followed up 25 hypertensive hemodialysis patients who completed 8-week aliskiren treatment in a previous study for 20 months to investigate the blood pressure-lowering effect and inhibitory effect on the renin-angiotensin-aldosterone system.

Results: Among the 25 patients, eleven patients continued with aliskiren treatment. Blood pressure ( \pm standard deviation) decreased from $175 \pm 18 / 80 \pm 11 \mathrm{mmHg}$ at baseline to $156 \pm 20 / 76 \pm 9 \mathrm{mmHg}$ at month 20. Plasma renin activity, angiotensin I, and angiotensin II decreased from baseline to month 20 (plasma renin activity $(\mathrm{ng} / \mathrm{mL} / \mathrm{h}): 2.3 \pm 2.6$ to $0.3 \pm 0.4$ $(P<0.05)$, angiotensin I $(\mathrm{pg} / \mathrm{mL}): 909.1 \pm 902.5$ to $41.5 \pm 14.8(P<0.05)$, angiotensin II (pg/mL): $41.5 \pm 45.8$ to $11.0 \pm 4.9(P<0.05))$.

Conclusion: Long-term treatment with aliskiren provides effective blood pressure lowering and inhibition of the renin-angiotensin-aldosterone system, which are sustained over 20 months in hypertensive hemodialysis patients.

Keywords: aliskiren, blood pressure, renin, angiotensin, aldosterone, hemodialysis patients, long-term effects

\section{Introduction}

Hypertension and cardiovascular disease (CVD) are common in hemodialysis (HD) patients. ${ }^{1-3}$ Recent meta-analyses demonstrated that antihypertensive pharmacotherapy reduced CVD in HD patients. ${ }^{4,5}$ The renin-angiotensin-aldosterone system (RAAS) contributes to hypertension and CVD in hypertensive HD patients. ${ }^{6,7}$ Previous studies suggested that RAAS blockers such as angiotensin I converting enzyme inhibitors (ACEIs) and angiotensin receptor blockers (ARBs) were effective for blood pressure (BP) control and CVD protection in hypertensive HD patients. ${ }^{8-13}$

In a previous study, we reported that an oral direct renin inhibitor, aliskiren, was effective for BP control and could have CVD protective effects in hypertensive HD patients in 8 -week treatment periods; ${ }^{14}$ however, its long-term effects in hypertensive HD patients remain to be elucidated. In this post hoc analysis, we followed up the hypertensive HD patients who completed the previous study for 20 months to investigate the BP-lowering effect and inhibitory effects on RAAS and surrogate markers of CVD, such as brain natriuretic peptide (BNP) and an oxidative stress marker, diacron-reactive oxygen metabolites (d-ROM), of aliskiren in hypertensive HD patients. 


\section{Methods}

This study was performed in accordance with the Declaration of Helsinki and was approved by the ethics committee of Jichi Medical University. Written informed consent was obtained from all patients.

\section{Patients and study protocol}

Details of the protocol of aliskiren for hypertensive HD patients in the 8-week trials in the previous study have been published previously. ${ }^{14}$ Briefly, the study was a multicenter clinical trial of 30 hypertensive HD patients. Subjects were enrolled between January 2010 and February 2010 and assigned aliskiren at $150 \mathrm{mg}$ orally in the morning once daily with their existing antihypertensives. The end point of the previous study was to determine the changes of RAAS, BP, and surrogate markers of CVD after 8 weeks of aliskiren treatment. After the end of the previous study, the continuation of aliskiren treatment was determined by physicians on basis of the patients' BP levels. As shown in Figure 1, in this post hoc analysis, we followed up the hypertensive HD patients who completed the previous study for 20 months to investigate the changes of BP, RAAS, and surrogate markers of CVD in both hypertensive HD patients who continued with aliskiren treatment (aliskiren group) and those who were withdrawn from aliskiren treatment (aliskiren-withdrawal group).

\section{Monitoring BP, RAAS, and CVD surrogate markers}

Systolic BP (SBP) and diastolic BP (DBP) were measured before all HD sessions. The reported monthly SBP and DBP were the average of each SBP and DBP on the last HD day of the week. Blood samples were obtained from arteriovenous shunt before HD sessions. Plasma renin activity (PRA), angiotensin I (AT I), angiotensin II (AT II), aldosterone (Ald), BNP, and d-ROM levels were compared at baseline and at months 2 and 20. Standard laboratory tests were performed in the observation period in each month in the treatment period.

\section{Laboratory methods}

PRA, Ald, and BNP levels were determined by the radioimmunoassay method. AT I and AT II levels were measured by a double antibody radioimmunoassay method; the details of these methods have been described elsewhere. ${ }^{15,16}$ PRA, AT I, AT II, BNP, and other blood chemistry levels were determined by a clinical chemistry laboratory (SRL, Inc, Tokyo, Japan). d-ROM values were measured using the Free

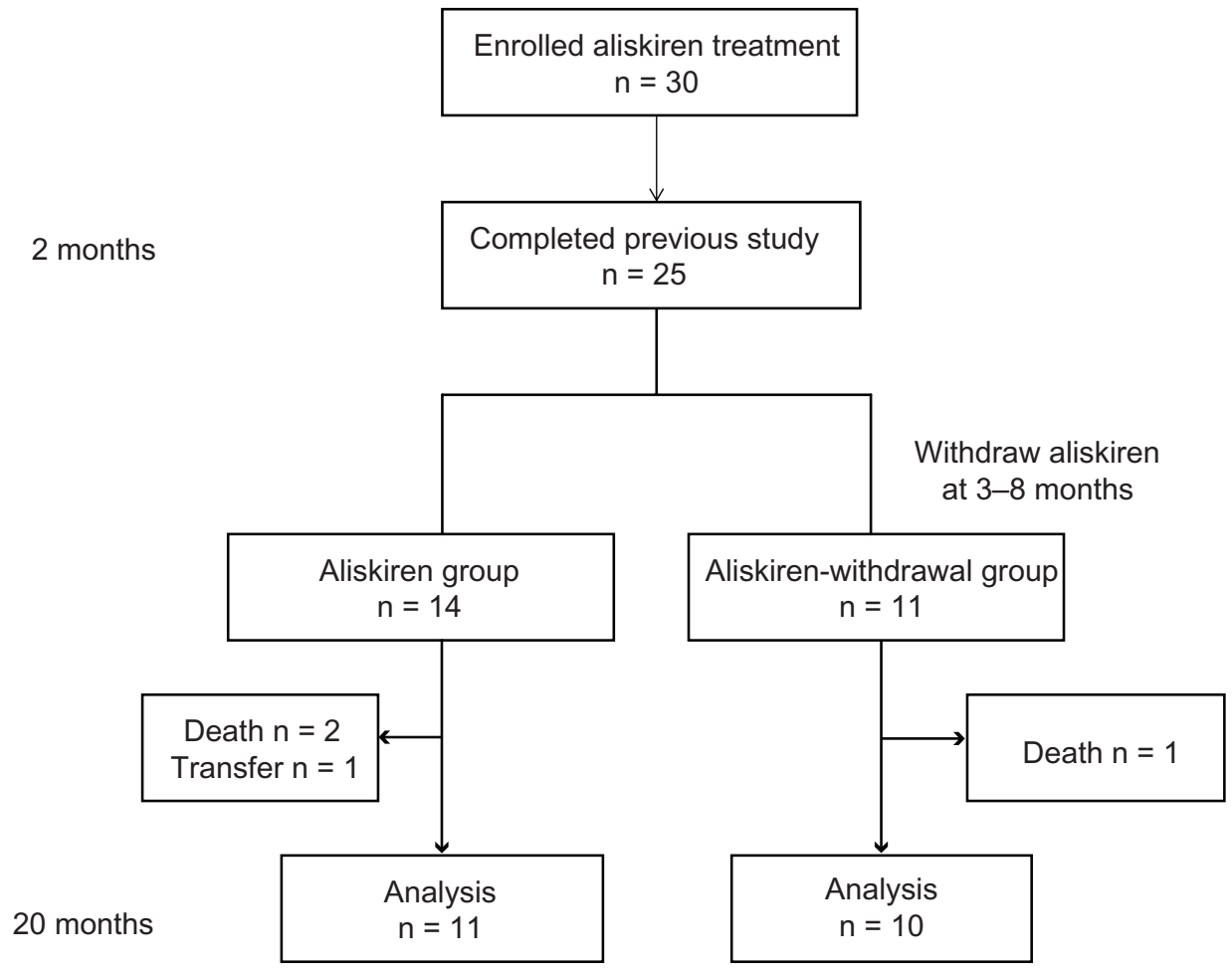

Figure I Patient flow chart. 
Radical Analysis System 4 (Wismerll, Tokyo, Japan); the details of this method have been described elsewhere. ${ }^{17,18}$

\section{Statistical analysis}

All data are expressed as the mean \pm standard deviation.

Baseline characteristics were compared between groups with unpaired $t$-test. The parameters within each group were compared with paired $t$-test. Differences with a $P$-value $<0.05$ were considered significant.

\section{Results}

In a previous study, 25 of 30 hypertensive HD patients completed an 8-week aliskiren treatment trial. Twenty-three of the 25 patients had been taking antihypertensive drugs before aliskiren treatment, including calcium antagonists (16 patients), ACEIs (six patients), ARBs (18 patients), $\beta$-blockers (four patients), $\alpha$-blockers (seven patients), $\alpha \beta$-blockers (four patients), and $\alpha$-methyldopa (five patients). Among these 25 patients, 11 patients continued aliskiren treatment with their pre-existing antihypertensives including calcium antagonists (four patients), ARBs (seven patients), $\beta$-blockers (two patients), and $\alpha$-blockers (three patients) during this study period (aliskiren group). Ten patients were withdrawn from aliskiren treatment from month 3 to month 8 (month 3, one patient; month 4, three patients; month 6 , two patients; month 7, two patients; and month 8, two patients) owing to symptomatic hypotension. These ten patients had their BP controlled by antihypertensives other than aliskiren including calcium antagonists (eight patients), ACEIs (three patients), ARBs (eight patients), $\beta$-blockers (two patients), $\alpha$-blockers (three patients), $\alpha \beta$-blockers (four patients), and $\alpha$-methyldopa (three patients) during this study period (aliskiren-withdrawal group). Two patients died of heart failure under aliskiren treatment (one patient) and after withdrawal from aliskiren treatment (one patient) and one patient died of pneumonia under aliskiren treatment. One patient was transferred to hospital. These four patients were excluded from analysis. Table 1 shows the characteristics of the study patients in both the aliskiren group and the aliskiren-withdrawal group at baseline. There were no statistical differences in age, body mass index, time on dialysis, average time of a dialysis, average ultrafiltration, and duration of hemodialysis between the aliskiren group

Table I Patients' baseline characteristics

\begin{tabular}{|c|c|c|c|}
\hline Parameter & Aliskiren group & Aliskiren-withdrawal group & $P$ value \\
\hline Number & 11 & 10 & \\
\hline Age (years) & $66.3 \pm 7.4$ & $67.2 \pm 8.1$ & 0.56 \\
\hline \multicolumn{4}{|l|}{ Gender } \\
\hline Male & 7 & 5 & \\
\hline Female & 4 & 5 & \\
\hline BMI $\left(\mathrm{kg} / \mathrm{m}^{2}\right)$ & $23.2 \pm 3.0$ & $23.8 \pm 3.1$ & 0.42 \\
\hline Time on dialysis (weeks) & $2.9 \pm 0.2$ & $2.8 \pm 0.2$ & 0.51 \\
\hline Average time of the dialysis (hours) & $4.0 \pm 0.2$ & $4.0 \pm 0.3$ & 0.63 \\
\hline Average ultrafiltration (kg/hours/HD section) & $2.8 \pm 1.1$ & $2.7 \pm 1.4$ & 0.81 \\
\hline Duration of hemodialysis (years) & $6.9 \pm 7.2$ & $6.8 \pm 6.2$ & 0.76 \\
\hline \multicolumn{4}{|l|}{ Initial nephropathy } \\
\hline Chronic glomerulonephritis & 2 & 2 & \\
\hline Diabetic nephropathy & 7 & 4 & \\
\hline ANCA-associated glomerulonephritis & 0 & 1 & \\
\hline Drug nephropathy & 0 & 1 & \\
\hline Malignant hypertension & I & 0 & \\
\hline Unknown & 1 & 2 & \\
\hline SBP $(\mathrm{mmHg})$ & $175.0 \pm 18.0$ & $171.0 \pm 13.0$ & 0.30 \\
\hline $\mathrm{DBP}(\mathrm{mmHg})$ & $80.0 \pm 11.0$ & $80.0 \pm 14.0$ & 0.89 \\
\hline HR (beats/minute) & $78.0 \pm 12.0$ & $76.0 \pm 10.0$ & 0.91 \\
\hline PRA (ng/mL/hr) & $2.3 \pm 2.6$ & $3.3 \pm 2.9$ & $0.4 I$ \\
\hline ATI (pg/mL) & $909.1 \pm 902.5$ & $999.1 \pm 844.6$ & 0.82 \\
\hline ATII (pg/mL) & $41.5 \pm 45.8$ & $30.6 \pm 36.7$ & 0.56 \\
\hline Ald (pg/mL) & $163.5 \pm 214.3$ & $97.2 \pm 57.5$ & 0.58 \\
\hline BNP (pg/mL) & $248.9 \pm 197.2$ & $425.3 \pm 207.3$ & 0.06 \\
\hline d-ROM (U.CARR) & $386.6 \pm 123.1$ & $402.3 \pm 69.0$ & 0.72 \\
\hline
\end{tabular}

Abbreviations: BMI, body mass index; HD, hemodialysis; ANCA, SBP, systolic blood pressure; DBP, diastolic blood pressure; HR, heart rate; PRA, plasma renin activity; ATI, angiotensin I; ATII, angiotensin II; Ald, aldosterone; BNP, brain natriuretic peptide; d-ROM, diacron-reactive oxygen metabolite; U.CARR, Carratelli units. 
and the aliskiren-withdrawal group at baseline (Table 1) and at month 2 (data not shown). Increased serum potassium was not observed in any patients in both the aliskiren group and the aliskiren-withdrawal group throughout the treatment period.

\section{Effect of aliskiren on BP}

Figure 2 shows the changes of SBP and DBP in the aliskiren group and the aliskiren-withdrawal group. There was no statistical difference in SBP and DBP between the aliskiren group and the aliskiren-withdrawal group at baseline (Table 1 and Figure 2) and at month 2 (Figure 2). There was also no difference in hypotension episodes during HD between the aliskiren group and the aliskiren-withdrawal group during the study period. SBP and DBP ( \pm standard deviation) decreased from $175 \pm 18 / 80 \pm 11 \mathrm{mmHg}$ at baseline to $156 \pm 20 / 76 \pm 9 \mathrm{mmHg}$ at month 2 and $155 \pm 19 / 76 \pm 9 \mathrm{mmHg}$ at month 20 in the aliskiren group. The SBP and DBP of patients who received $A R B s$ and those who did not receive $A R B s$ did not show a difference in the aliskiren group during the study period. SBP and DBP ( \pm standard deviation) also decreased from $171 \pm 13 / 80 \pm 14 \mathrm{mmHg}$ at baseline to $159 \pm 17 / 79 \pm 12 \mathrm{mmHg}$ at month 2 and $157 \pm 26 / 77 \pm 12 \mathrm{mmHg}$ at month 20 in the aliskirenwithdrawal group. Although a trend of lower SBP was detected in the aliskiren-withdrawal group between month 4 and month 7, SBP and DBP did not show a statistical difference between the aliskiren group and the aliskirenwithdrawal group throughout the follow-up period.

\section{Blockade of RAAS by aliskiren}

Each factor of RAAS at baseline in both the aliskiren group and the aliskiren-withdrawal group is shown in Table 1. There were no statistically significant differences in each factor of RAAS between the aliskiren group and the aliskiren-withdrawal group at baseline (Table 1 and Figure 3) and at month 2 (Figure 3). In the aliskiren group, PRA, AT I, AT II, and Ald decreased from baseline to month 2, and this decreased level continued at month 20 (PRA (ng/mL/h): $2.3 \pm 2.6$ (baseline) $-0.5 \pm 0.5$ (month 2) $(P<0.05)-0.3 \pm 0.4$ (month 20) $(P<0.05)$, AT I $(\mathrm{pg} /$ $\mathrm{mL}): 909.1 \pm 902.5$ (baseline) $-271.7 \pm 166.0$ (month 2$)(P$ $<0.05)-41.5 \pm 14.8$ (month 20) $(P<0.05)$, AT II $(\mathrm{pg} / \mathrm{mL})$ : $41.5 \pm 45.8$ (baseline) $-10.0 \pm 9.9$ (month 2$)(P<0.05)-$ $11.0 \pm 4.9$ (month 20$)(P<0.05)$, Ald $(\mathrm{pg} / \mathrm{mL}): 163.5 \pm 214.3$ (baseline) $-74.2 \pm 33.2$ (month 2$)(P=0.29)-63.4 \pm 20.0$ (month 20) $(P=0.09)$ ) (Figure 2). On the other hand, in the aliskiren-withdrawal group, although PRA, AT I, AT II, and Ald decreased at month 2 with aliskiren treatment (PRA (ng/ $\mathrm{mL} / \mathrm{h}): 3.3 \pm 2.9$ (baseline) $-0.9 \pm 0.7$ (month 2$)(P<0.05)$, AT I $(\mathrm{pg} / \mathrm{mL}): 999.1 \pm 844.6$ (baseline) $-365.6 \pm 211.6$ (month 2) $(P<0.05)$, AT II $(\mathrm{pg} / \mathrm{mL}): 30.6 \pm 36.7$ (baseline) $-8.4 \pm 10.7$ (month 2$)(P<0.05)$, Ald $(\mathrm{pg} / \mathrm{mL})$ : $97.2 \pm 57.5$ (baseline) $-79.3 \pm 35.7$ (month 2$)(P=0.25))$, they increased to the level of baseline upon withdrawal

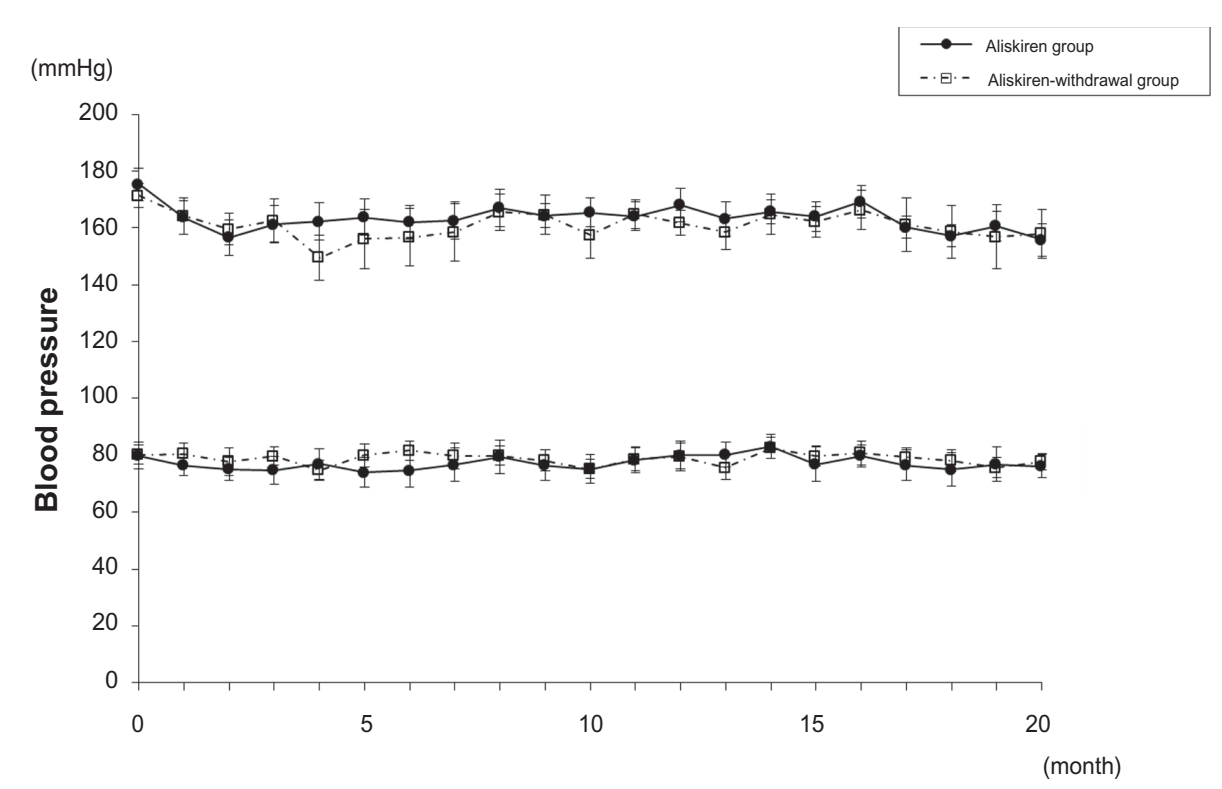

Figure 2 Changes in systolic blood pressure and diastolic blood pressure from baseline (week 0) to month 20 in the aliskiren group and the aliskiren-withdrawal group. 

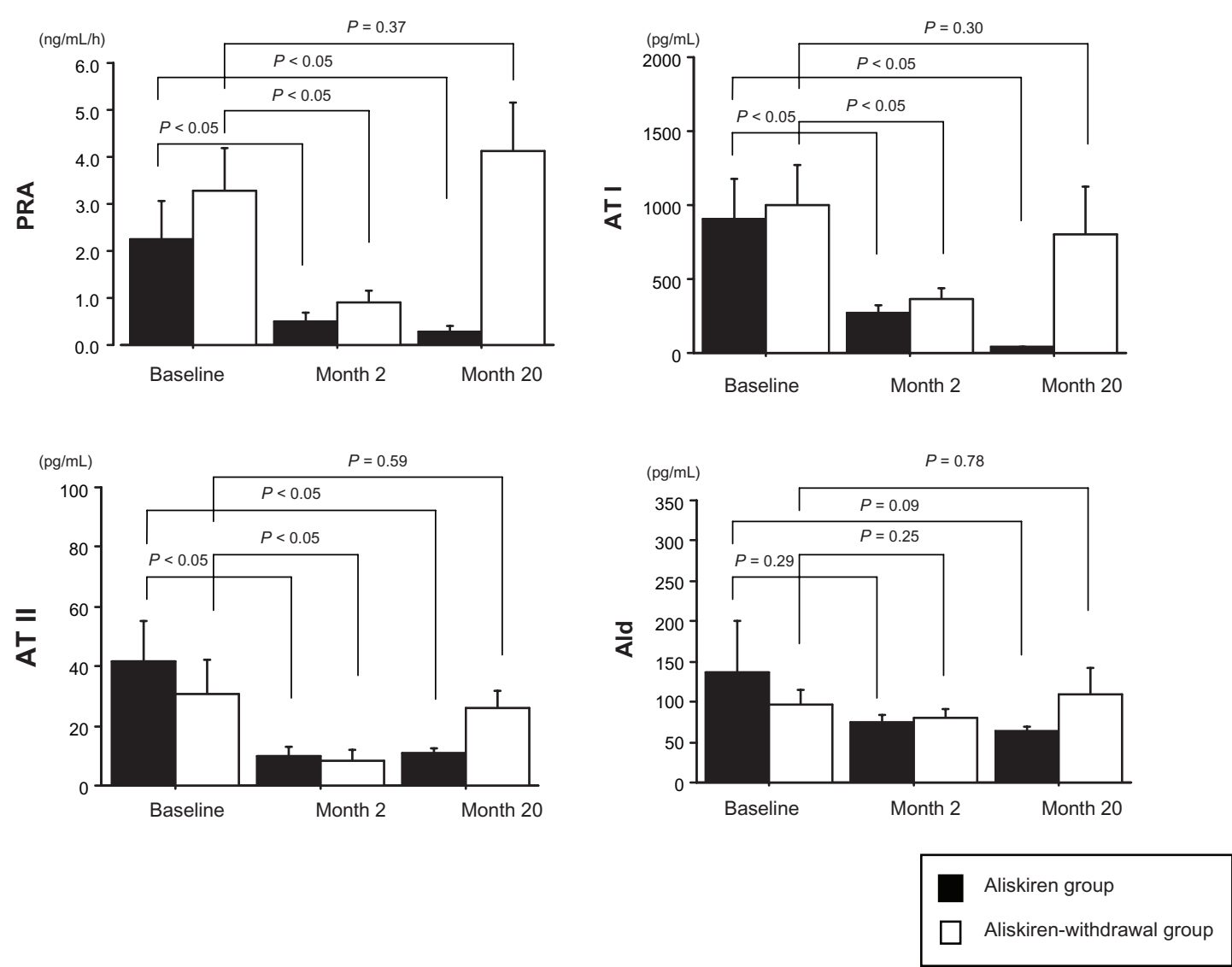

Figure 3 Changes in plasma renin activity (PRA), angiotensin I (AT I), angiotensin II (AT II), and aldosterone (Ald) from baseline to month 2 and month 20 in the aliskiren group and the aliskiren-withdrawal group.

of aliskiren at month $20($ PRA $(\mathrm{ng} / \mathrm{mL} / \mathrm{h}): 4.1 \pm 3.3$ $(P=0.37)$, AT I $(\mathrm{pg} / \mathrm{mL}): 801.0 \pm 1032.8(P=0.30)$, AT II (pg/mL): $26.1 \pm 17.2(P=0.58)$, Ald $(\mathrm{pg} / \mathrm{mL}): 108.8 \pm 106.7$ $(P=0.78))$ (Figure 3).

\section{Inhibition of BNP and d-ROM by aliskiren}

Although there were no statistically significant differences in BNP and d-ROM level between the aliskiren group and the aliskiren-withdrawal group at baseline and at month 2, BNP showed a tendency to be higher in the aliskiren-withdrawal group (Table 1). In the aliskiren group, although there was no statistical significance, BNP and d-ROM tended to decrease from baseline to month 2 followed by a further decrease at month 20 (BNP (pg/mL): $248.9 \pm 197.2$ (baseline) $-232.8 \pm 133.1(P=0.71)($ month 2$)-203.7 \pm 113.3$ $(P=0.53)$ (month 20), d-ROM (Carratelli Units [U.CARR]): $386.6 \pm 123.1$ (baseline) $-356.3 \pm 120.5(P=0.16)$ (month 2) $-305.6 \pm 67.4(P=0.08)$ (month 20)) (Figure 4). On the other hand, in the aliskiren-withdrawal group, BNP initially showed a tendency to decrease from baseline to month 2; however, it did not decrease from month 2 to month 20 (BNP (pg/mL): $425.3 \pm 207$ (baseline) $-409.5 \pm 287.8$ $(P=0.82)$ (month 2$)-412.9 \pm 287.8(P=0.88)$ (month 20)) (Figure 4). d-ROM tended to decrease from baseline to month 2 followed by a further decrease at month 20 (d-ROM (U.CARR): $402.3 \pm 69.0$ (baseline) $-362.3 \pm 47.8$ $(P=0.09)$ (month 2$)-336.3 \pm 58.5(P=0.07)($ month 20$))$ (Figure 4).

\section{Discussion}

The results of this study show that aliskiren significantly decreased SBP and DBP as well as inhibited RAAS for the long term in hypertensive HD patients. The aliskiren-withdrawal patients showed re-upregulation of RAAS although their SBP and DBP were controlled at levels similar to those of the aliskiren group by antihypertensives, except for RAAS blockers. These results suggest that aliskiren significantly inhibited RAAS and had BP-lowering effects in hypertensive HD patients for the long-term. In addition, although statistical significance was not reached, which was considered to be 

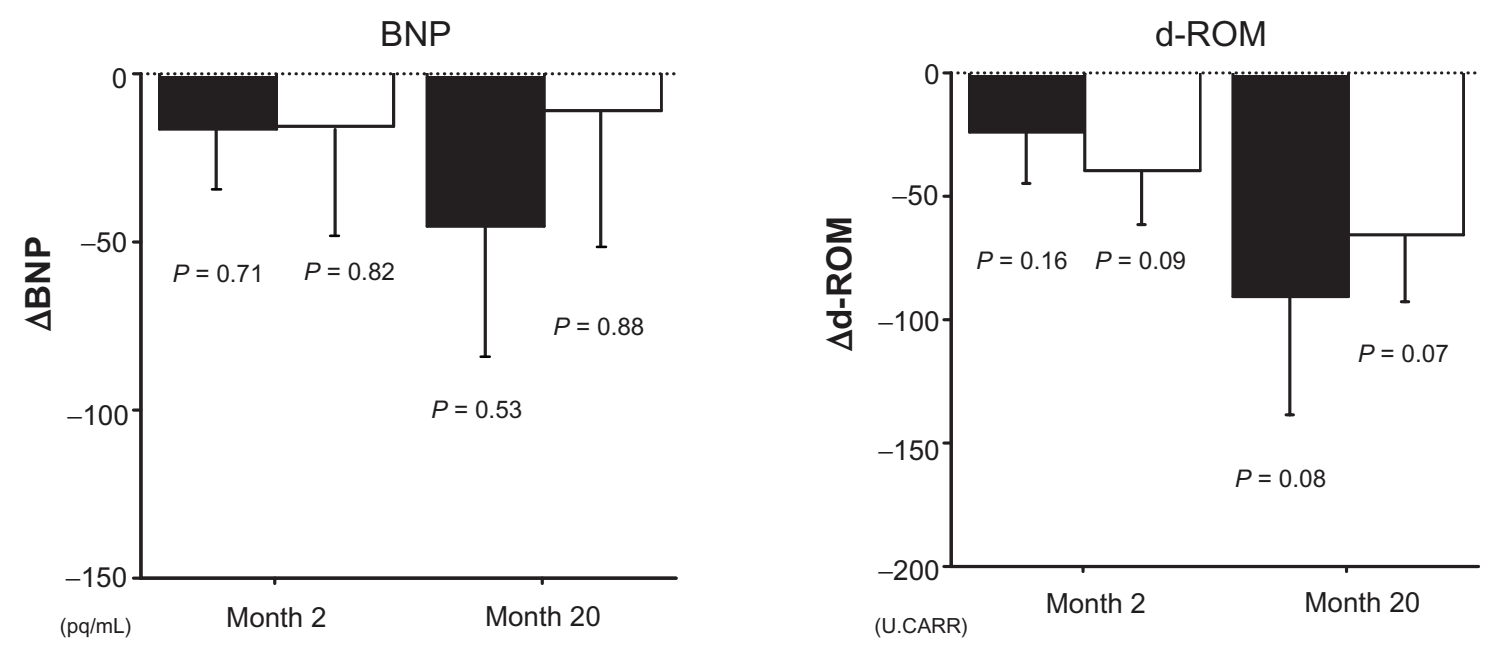

Aliskiren group

Aliskiren-withdrawal group

Figure 4 Changes in brain natriuretic peptide $(\triangle \mathrm{BNP})$ and diacron-reactive oxygen metabolite $(\Delta \mathrm{d}$-ROM) from baseline to month 2 and month 20 in the aliskiren group and the aliskiren-withdrawal group.

due to the small number of samples, BNP (pg/mL) decreased from baseline $(248.9 \pm 197.2)$ to month $2(232.8 \pm 133.1)$ followed by a further decrease at month 20 (203.7 \pm 113.3$)$ in the aliskiren group. On the other hand, in the aliskirenwithdrawal group, although BNP (pg/mL) decreased from baseline $(425.3 \pm 207.3)$ to month $2(409.5 \pm 287.8 \mathrm{pg} / \mathrm{mL})$ with aliskiren treatment, it did not decrease from month 2 to month $20(412.9 \pm 287.8 \mathrm{pg} / \mathrm{mL})$ by withdrawal of aliskiren under similar levels of SBP and DBP as those of the aliskiren group. BNP reduction has consistently been associated with an improved outcome in heart failure. ${ }^{19-21}$ For instance, an increment of $10 \mathrm{pg} / \mathrm{mL}$ in BNP was associated with a $1.2 \%$ increased risk of death. ${ }^{19}$ Although we did not perform echocardiography to monitor the change of cardiac functions by aliskiren treatment during this period, these results suggested that both the aliskiren group and the aliskiren-withdrawal group may not exhibit worse cardiac functions. In addition, aliskiren might have cardioprotective effects in hypertensive HD patients. On the other hand, the oxidative stress marker d-ROM (U.CARR) showed a decrease from baseline to month 2 followed by a further decrease at month 20 in both the aliskiren group (386.6 \pm 123.1 (baseline) $-356.3 \pm 120.5$ (month 2) - 305.6 \pm 67.4 (month 20)) and the aliskiren-withdrawal group $(402.3 \pm 69.0$ (baseline) $-362.3 \pm 47.8$ (month 2 ) $-336.3 \pm 58.5$ (month 20)). These results suggest that d-ROM may be decreased in association with BP lowering in hypertensive HD patients. Side effects of aliskiren including hyperpotassemia were not detected in any patients throughout the follow-up period in both the aliskiren group and the aliskiren-withdrawal group.

We previously reported that aliskiren was effective for BP control and inhibition of RAAS in hypertensive HD patients in the short-term, namely, by 8 weeks of analysis. ${ }^{14}$ Since the rate of discontinuation of aliskiren treatment $(150 \mathrm{mg} /$ day $)$ owing to symptomatic hypotension was high (eleven of 25 patients) in this study, it may be better to reduce the initial dose of aliskiren to less than $150 \mathrm{mg}$ /day, and careful observation for BP change is required for aliskiren treatment in hypertensive HD patients. Further studies including kinetic analysis of aliskiren will need to investigate the optimal dose of aliskiren in hypertensive HD patients. Taken together, the results of this study suggest that aliskiren is effective for BP control and inhibition of RAAS, which may lead to cardiovascular protective effects in hypertensive HD patients in the long term, although they need careful monitoring of BP change.

\section{Disclosure}

All authors report no conflicts of interest in this work.

\section{References}

1. Agarwal R, Nissenson AR, Batlle D, Coyne DW, Trout JR, Warnock DG. Prevalence, treatment, and control of hypertension in chronic hemodialysis patients in the United States. Am J Med. 2003;115(4): 291-297. 
2. Collins AJ, Roberts TL, St Peter WL, Chen SC, Ebben J, Constantini E. United States Renal Data System assessment of the impact of the National Kidney Foundation-Dialysis Outcomes Quality Initiative guidelines. Am J Kidney Dis. 2002;39(4):784-795.

3. Herzog CA, Ma JZ, Collins AJ. Long-term survival of dialysis patients in the United States with prosthetic heart valves: should ACC/AHA practice guidelines on valve selection be modified? Circulation. 2002;105(11):1336-1341.

4. Agarwal R, Sinha AD. Cardiovascular protection with antihypertensive drugs in dialysis patients: systematic review and meta-analysis. Hypertension. 2009;53(5):860-866.

5. Heerspink HJ, Ninomiya T, Zoungas S, et al. Effect of lowering blood pressure on cardiovascular events and mortality in patients on dialysis: a systematic review and meta-analysis of randomised controlled trials Lancet. 2009;373(9668):1009-1015.

6. Blankestijn PJ, Ligtenberg G. Volume-independent mechanisms of hypertension in hemodialysis patients: clinical implications. Semin Dial. 2004;17(4):265-269.

7. Laragh JH. Renin profiling for diagnosis, risk assessment, and treatment of hypertension. Kidney Int. 1993;44(5):1163-1175.

8. Matsumoto N, Ishimitsu T, Okamura A, Seta H, Takahashi M, Matsuoka H. Effects of imidapril on left ventricular mass in chronic hemodialysis patients. Hypertens Res. 2006;29(4):253-260.

9. Wauters JP, Waeber B, Brunner HR, Guignard JP, Turini GA, Gavras H. Uncontrollable hypertension in patients on hemodialysis: long-term treatment with captopril and salt subtraction. Clin Nephrol. 1981;16(2): 86-92.

10. Saracho R, Martin-Malo A, Martinez I, Aljama P, Montenegro J. Evaluation of the Losartan in Hemodialysis (ELHE) Study. Kidney Int Suppl. 1998;68:S125-S129.

11. Shibasaki Y, Masaki H, Nishiue T, Nishikawa M, Matsubara H, Iwasaka T. Angiotensin II type 1 receptor antagonist, losartan, causes regression of left ventricular hypertrophy in end-stage renal disease. Nephron. 2002;90(3):256-261.
12. Kanno Y, Kaneko K, Kaneko M, et al. Angiotensin receptor antagonist regresses left ventricular hypertrophy associated with diabetic nephropathy in dialysis patients. $J$ Cardiovasc Pharmacol. 2004;43(3): 380-386.

13. Morishita Y, Kusano E. The blockade of renin-angiotensin-aldosterone system in hemodialysis patients to control hypertension and prevent cardiovascular disease: optimal pharmacotherapy. Cardiovasc Hematol Agents Med Chem. 2011. Epub Oct 21.

14. Morishita Y, Hanawa S, Chinda J, Iimura O, Tsunematsu S, Kusano E. Effects of aliskiren on blood pressure and the predictive biomarkers for cardiovascular disease in hemodialysis-dependent chronic kidney disease patients with hypertension. Hypertens Res. 2011;34(3):308-313.

15. Emanuel RL, Cain JP, Williams GH. Double antibody radioimmunoassay of renin activity and angiotensin II in human peripheral plasma. J Lab Clin Med. 1973;81(4):632-640.

16. Rodbard D. Statistical quality control and routine data processing for radioimmunoassays and immunoradiometric assays. Clin Chem. 1974;20(10):1255-1270.

17. Cesarone MR, Belcaro G, Carratelli M, et al. A simple test to monitor oxidative stress. Int Angiol. 1999;18(2):127-130.

18. Gerardi G, Usberti M, Martini G, et al. Plasma total antioxidant capacity in hemodialyzed patients and its relationships to other biomarkers of oxidative stress and lipid peroxidation. Clin Chem Lab Med. 2002;40(2): 104-110.

19. Latini R, Masson S, Anand I, et al. The comparative prognostic value of plasma neurohormones at baseline in patients with heart failure enrolled in Val-HeFT. Eur Heart J. 2004;25(4):292-299.

20. Latini R, Masson S, Wong $\mathrm{M}$, et al. Incremental prognostic value of changes in B-type natriuretic peptide in heart failure. Am J Med. 2006;119(1):70, e23-e30.

21. Jourdain P, Jondeau G, Funck F, et al. Plasma brain natriuretic peptideguided therapy to improve outcome in heart failure: the STARS-BNP Multicenter Study. J Am Coll Cardiol. 2007;49(16):1733-1739.

\section{Publish your work in this journal}

The International Journal of Nephrology and Renovascular Disease is an international, peer-reviewed open-access journal focusing on the pathophysiology of the kidney and vascular supply. Epidemiology, screening, diagnosis, and treatment interventions are covered as well as basic science, biochemical and immunological studies. The journal welcomes

\section{Dovepress}

original research, clinical studies, reviews \& evaluations, expert opinion and commentary, case reports and extended reports. The manuscript management system is completely online and includes a very quick and fair peerreview system, which is all easy to use. Visit http://www.dovepress.com/ testimonials.php to read real quotes from published authors 